BENTHAM OPEN
CrossMark
Content list available at: www.benthamopen.com/TODIAJ/
DOI: $10.2174 / 1876524601808010022,2018,8,22-33$

SYSTEMATIC REVIEW

\title{
Type 2 Diabetes Treatment and Drug Development Study
}

Da-Yong Lu ${ }^{1, *}$, Jin-Yu Che ${ }^{1}$, Nagendra Sastry Yarla ${ }^{2}$, Hong-Ying Wu ${ }^{1}$, Ting-Ren $\mathrm{Lu}^{1}$, Bin Xu ${ }^{3}$, ShuYun $\mathrm{Wu}^{3}$, Jian Ding ${ }^{3}$, Yi $\mathrm{Lu}^{4}$ and Hong $\mathrm{Zhu}^{5}$

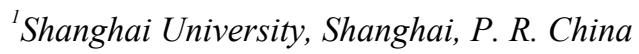

${ }^{2}$ Divisions of Biochemistry and Chemistry, City University of New York School of Medicine, 160 Convent Avenue, New York, NY 10031, USA

${ }^{3}$ Shanghai Institute of Materia Medica, Chinese Academy of Sciences, Shanghai, P. R. China

${ }^{4}$ Shanghai Ocean University, Shanghai, P. R. China

${ }^{5}$ College of Pharmaceutical Science, Zhejiang University, Hangzhou, P. R. China

Received: May 15, 2018

Revised: July 5, 2018

Accepted: July 16, 2018

Abstract: The causality and etio-pathologic risks for patients with Type 2 Diabetes (T2DM) are important areas in modern medicine. Disease complications are largely unpredictable in patients with T2DM. In the future, we welcome therapeutics of both cutting-edge and traditional for anti-diabetic treatments and management with higher efficiency and less cost. Expanding medical knowledge, behavior/life-style notification in healthcare, modern genetic/bioinformatics diagnostic promotion, clinical developments (Traditional Chinese Medicine and personalized medicine) and new drug developments - including candidate drug targets should be implemented in the future. These efforts might be useful avenues for updating anti-diabetic therapeutics globally. This article aims at introducing this information for T2DM treatment boosts.

Keywords: Diabetes Mellitus, Diabetes therapy, Medical education, Type 2 diabetes, Insulin-derivatives, Bee extract, Cardiovascular complication, Hyperglycemia, Traditional Chinese Medicine.

\section{INTRODUCTION}

The prevalence of Type 2 Diabetes (T2DM) is reaching a critical stage in developing and developed countries worldwide approximately 15\% morbidity rates globally - including China, Indian, US and others due to lack of therapeutic options for disease cure in a great part of patients with T2DM [1 - 5]. For this reason, global medical expenses for anti-diabetic treatments are growing rapidly [1 - 5]. However, many key elements related to diabetes causality, pathogenesis and therapy are still waiting for the unveiling.

The quality of experimental or clinical diabetes study has been varied owing to the divergent patient's physiological conditions, disease stage and therapeutic differences. Some agents might target on blood glucose level control and some others might be associated with insulin- or genetic-related pathways. As a tough medical challenge, new conditions may be met from the developments of multi-functional therapeutics. Different areas of top medical challenge to anti-diabetic managements are highlighted in the following sectors.

\section{OVERALL LANDSCAPES}

\subsection{T2DM Causality and Etio-Pathogenesis}

Developing T2DM might undergo a lengthy and complex course, even pathogenesis cascade processes, in susceptible human beings. Some of them are even partly family inheritable diseases, like obesity and hypertension. Yet the T2DM pathogenesis processes and cascade are often difficultly reversed. Onset stage can more easily slow down

\footnotetext{
* Address correspondence to this author at the Shanghai University, Shanghai, P. R. China; Email: ludayong@shu.edu.cn
} 
disease progression and reduce patient's morbidity rates in general people. A reliable, long-lasting and multi-functional medical education of diabetes may arise the attention of wider populations, especially to old persons who are more susceptible to T2DM events. Given asymptomatic in early stages of T2DM, regular blood glucose level checkup in persons ( $>40$ years old or in sedentary occupation) is introduced.

Apart from food consumption control, some other unfavorable factors, such as habitually heavy drunk, long-term depression, sleep problem, genetic mutations/variations, obesity or sleep apnea etc. [2 - 19]. can also be the culprits of T2DM causality and pathogenesis. Thus, regular medical checks including blood glucose levels and other metabolic syndrome should be monitored as early as possible.

\subsection{The Type 2 Diabetes Causality List-up}

The origin of T2DM is unclear and not fixed - including molecular pathways of insulin-insufficient as well as functional resistance. Following factors are suggested to be involved in this lengthy process of insulin-resistance and disease onset:

1. Fetus nutritional insufficient

2. Energy imbalance (overfeed or shortage of mobile activity)

3. Bad habits (over drunk etc.)

4. Heritage (genetic or epigenetics)

5. Neural-appetite axis

6. Sleep problem (apnea or insomnia)

7. Lack of enough exercises (sedentary occupation)

8. Mental depression

9. Hormonal-related

10. Other metabolic causality (obesity)

11. Drug-related (liver function impairment)

and so on [6 - 19].

Regarding this relevant etio-pathologic originality, different therapeutic intervention and anti-diabetic drugs are met with this metabolic abnormality.

The medical intervention for patients with diabetes at an early stage is a way of reducing further metabolic complication events and human mortality. To attain this goal, educational work to wider audience is noteworthy (Table 1).

Table 1. Medical education targets.

\begin{tabular}{|c|c|}
\hline Population Categories & Information \\
\hline $\begin{array}{c}\text { Doctors in big hospital } \\
\text { Doctors in rural or remote area } \\
\text { Medical students in colleges }\end{array}$ & $\begin{array}{c}\text { New ideas and clinical paradigm establish } \\
\text { Ways of type 2 diabetes diagnostics \& treatments in rural area } \\
\text { Interests in diabetes study, Basic knowledge of diabetes }\end{array}$ \\
\hline $\begin{array}{c}\text { Pharmacologists } \\
\text { Pharmaceutical scientists }\end{array}$ & $\begin{array}{c}\text { Different modes of diabetes treatments and drug development } \\
\text { Different types and forms of therapeutic drugs }\end{array}$ \\
\hline $\begin{array}{c}\text { Patients with T2DM } \\
\text { General populations at high risks } \\
\text { Normal people }\end{array}$ & $\begin{array}{c}\text { Understand the relationship between diagnostics and treatments } \\
\text { Awareness of diabetes-induced complications }\end{array}$ \\
\hline
\end{tabular}

\section{DRUG DEVELOPMENTS AND THERAPEUTIC VERIFICATION IN THE CLINIC}

\subsection{Patho-Therapeutic Processes}

Deeper understanding into pathologic/pharmacologic processes as well as mechanisms of action of a number of anti-diabetic drug is noteworthy and indispensable. To develop targeted drugs (higher therapeutic-index), pathologypharmacology association study (diabetic progress and complications), especially in the field of human heritable characters and genetic predisposition must be boosted $[11,12]$. But it still needs a longer time to finish.

In the initial stage, doctors and pharmacologists focused on blood glucose control - interfering or sabotaging food intake and digestions with compounds similar to glucose. To promote new therapeutic ideas, the top culprit of T2DM 
should be diversities and widen - at least not solely dependent on glucose itself. Accordingly, we should not rely on one or two therapeutic pathways. Novel events should be noticed and identified from experimental and clinical study.

In the real pathogenesis scenario of T2DM, insulin-binding or -related metabolism dysfunction, such as loss functions of pancreas island B-cells [17], liver metabolism problems [18], insulin resistance [19] and other heritable mutants and variations by unfavorable family lineages) are noticed (Table 2). According to this concept, many in vitro glucose-related studies are especially difficult to realize. Due to this limitation, anti-diabetic therapeutic study is widely debated. To overcome this obstacle, new experimental model selection (animal) or clinical developments must be established. Current pathogenesis and mechanisms of anti-DM drugs are generally outlined in Table 2 according to pharmacological categories [11, 12].

Generally speaking, chemo-therapeutic drugs for T2DM are not without toxicity. Though many chemotherapeutic drugs for T2DM are not very toxic comparing with other drug categories, their therapeutic responses need a relatively long term to exhibit and incurable. Prescribing optimal drug doses or schedules in specific diabetes conditions in individual patients has to be renewed and wider application. Long-term adjustments for drug dosing and schedule require interaction and cooperation between doctors and patients (Table 2 and Fig. 1). As a result, large-scale pharmacologic or clinical study is indispensable and long awaited.

\section{Early stages of patients with T2DM}

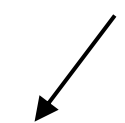

Lifestyle

Behavior
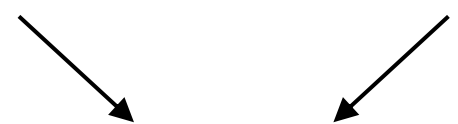

\section{Counteractive options against disease causalities}

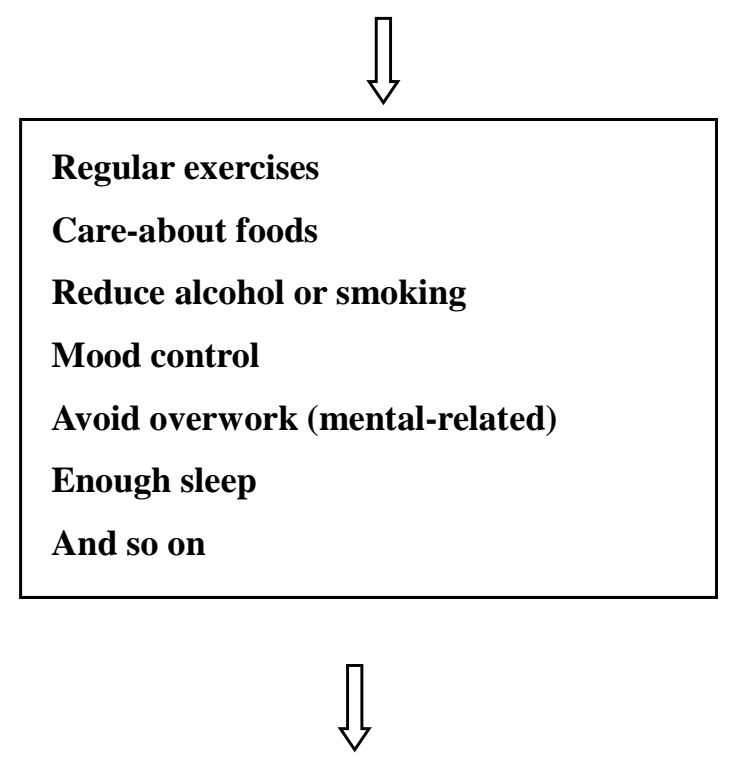

Find out if it is useful

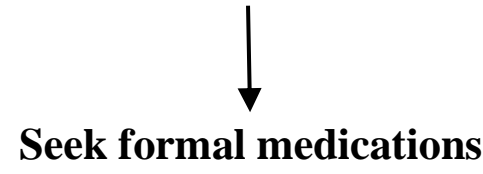

(Insulin or other chemical-/biological drugs)

Fig. (1). Preventive and treatment measures for patients with T2DM. 
Table 2. Different modes of drugs and therapeutics for type 2 diabetes [11, 12].

\begin{tabular}{|c|c|c|}
\hline Targets & Pathways and Symptoms & Personal Opinions \\
\hline Glucose & $\begin{array}{c}\text { Decrease glucose concentrations in animal and human by glucose metabolism interference } \\
\text { Substitute or compete food glucose intake with other mono carbohydrates or glucose- } \\
\text { derivatives }\end{array}$ & $\begin{array}{c}\text { Controversy } \\
\text { Controversy }\end{array}$ \\
\hline Insulin & $\begin{array}{c}\text { Human insulin and its derivatives } \\
\text { Modulators of pancreatic island B-cell } \\
\text { Muscle content and insulin-receptor } \\
\text { Potential } \\
\text { Important } \\
\text { Future trends }\end{array}$ \\
\hline Pisease complications & Cardiovascular complications \\
& $\begin{array}{c}\text { Nephropathy } \\
\text { Obesity }\end{array}$ & Potential and need to be improved \\
\hline Hepatic functions & Chronic leg infection etc. & Future trend \\
\hline Genetic changes & Ameliorate of damaged cells and metabolism & Promising \\
\hline Leg ischemic & Gene therapy or other biomedical therapies & Not satisfactory \\
\hline Life styles & Surgery & Adherence \\
& Persistence \\
\hline
\end{tabular}

\section{OVERVIEW OF CLINICAL STUDIES}

\subsection{Personalized Diabetes Therapy (PDT)}

It is possible that the clinical symptoms, stages and event of blood glucose escalation may vary among different people in the clinic, especially in the aspect of human genome. As a result, T2DM treatments for each patient should not be uniform. PDT based on genomic alterations may be a futuristic medical hot-spot that will enable doctors to provide optimal therapeutics for individual patients with T2DM [19 - 23]. Nonetheless, PDT should not be restricted to pharmacogenetics (PG) technology alone as it is now solely reliant in the clinic globally [19 - 25]. At this stage of technical capability, PG study mainly focuses on drug concentration in human blood by detecting Single Nucleotide Polymorphisms (SNPs) of human metabolic enzymes (approximately 300 metabolic molecules in normal human body), modern chromatography and capillary electrophoresis. Despite a lot of PG study and report for diabetic therapy, it is not applied as diagnostic routines in general hospitals worldwide. Like PG for cancer treatment [23], approaches outside of the scope of the current diagnostic/therapeutic system might be invented in the future.

\subsection{Bioinformatics and Metabolomics Techniques in the Clinic}

Bioinformatics/metabolomics techniques for diabetic pathology and treatments are more straightforward compared with genetic information variations and explanations (Fig. 2). Fig. (2) depicts an outlook of different possibilities of PDT under investigations. This type of PDT may be utilized in future anti-diabetic treatments and have a great potentiality and biomedical significance other than PG.

\section{PHARMACEUTICAL AND PHARMACOLOGIC INVESTIGATION}

\subsection{Higher Therapeutic-index Drug Developments}

Since only small spectra of drugs can play a decisive role against T2DM, anti-diabetic drugs may be given life-long. An ultimate goal of drug developer and pharmaceutical company is to produce a reliable, safe and low toxic drugs. Likely, it is one of the major avenues in the fields of T2DM therapeutic studies and clinical drug applications [25 - 29].

Many synthetic drugs are commonly cheaper yet low therapeutic-index for human disease treatments. As the safest and first-line anti-hyperglycemia therapeutics, insulin and insulin-derivatives can be used for both type I and type II Diabetes mellitus therapeutics according to different lines of clinical situations [26]. Yet it is very difficult to adjust insulin dosage in these patients. It also has some drawbacks - injection syringes after food intakes. Besides, it is not always good news for possible low blood glucose levels $(3.5-3.8 \mathrm{mmol} / \mathrm{L})$ due to insulin or drug overdosing (a lifethreatening event). 


\section{Patient enrollments}

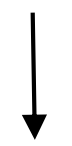

Disease notifications

(Blood glucose or insulin levels)

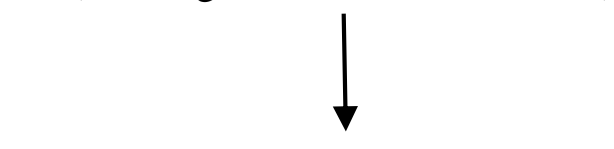

Disease symptoms and complications

(Genetic, molecular, metabolomics and physiological)<smiles>C[13CH3]</smiles>

Drug dosing, schedule and combinations

(Pharmacogenetics, modern chromatography and so on)

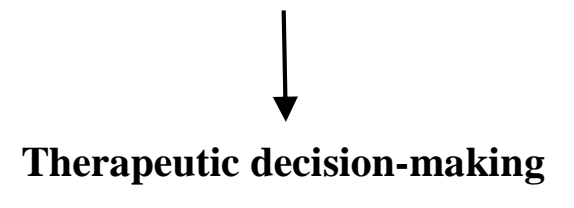

(Drug choice and therapeutic optimal)

Fig. (2). Proposed diagram of personalized Diabetes mellitus therapy.

\subsection{New Drug Pharmaceutical Designs}

Currently, oral intake of drugs is an environmental-friendly option for general patients. In the future, large-pool of small-molecular chemical pipelines by a computing system may add promising drug categories for T2DM [24]. If breakthrough achievement, new generations of highly effective, pharmaceutical-friendly chemical agents might be developed for oral insulin-like therapeutics for patients with T2DM [28 - 31].

\subsection{New Insulin-delivery System}

More recently, it has been invented that some capsules containing insulin can be given to patients with T2DM. This pharmaceutical innovation might achieve greater success in insulin treatments for patients with diabetes in the future.

\section{NATURAL CHEMOTHERAPEUTIC DRUGS, HERBS AND MEDICINES}

\subsection{Traditional Chinese Medicine (TCM)}

TCM has a long history and reports to notice many symptoms of diabetes. Certain numbers of herbs and recipes have been described in TCM books and legends to counteract with these unfavorable symptoms and diseases. As modern Chinese pharmacologist and doctors, we offer a brief introduction to this matter.

From the views of TCM, type 2 diabetes is likely as symptoms categories of blockage of key factors for physiological circulations or pathways; include (Tan-Shi-Ti-Zheng 痰湿体症 damp-phlegm syndrome); (Shi-Re- 
Ti-Zheng, 湿热体症 damp-heat syndrome) or (Xue-Yu-Ti-Zheng, 血瘀体症 - blood/qi circulation stasis and syndromes). Doctors may prescribe patients with this herbal mixture against the abnormality of physiological circulations or pathways.

Many natural plants or organisms ( $>500$ species) are proposed to show therapeutic against type 2 diabetes globally. They are a commonly crude plant, insect or animal products. Crude plants include leaf of Cyclocarya paluris (青钱柳), mulberry leaf (桑叶) and root of remembranous milk vetch (黄芪), milk thistle (水飞䔡) and many others.

Good therapeutic drugs need to not only reduce blood glucose levels but also act on wholesome physiological conditions in human beings. Natural chemotherapeutic drugs or other ancient therapeutic options are more suitable to meet with this modern challenge [32, 33].

\subsection{Supportive Agents}

Besides herbal medicine, some examples of insect or food products are also widely recognized to control the symptoms of T2DM [34 - 36].

Propolis is bee extract of waxy-like components extracted from crude honey. It was licensed as healthy-promoting agents yet practiced as hyperglycemia control for patients with T2DM [34, 35].

In Japan, some fermented soybeans (Natto) are also famous for T2DM-induced metabolic complication therapeutics. These fermented soybeans (Natto) can smooth human blood vessels (diabetes-induced cardiovascular complications), break phlegm-damp syndrome, blood/Qi stasis and many others [36]. Similar products will be developed against T2DM in new pathways.

\subsection{Biotherapy}

Since diabetes is a metabolic disease from endocrine abnormality, human biomolecules (such as insulin, microRNA, genomic modified bio-agents and so on) might be unique options for the disease control. However, most of the biomolecules are short-lived. Thus, pharmaceutical processes to add organic ligands/chains to bio-molecules (new delivery systems) are common routes for pharmaceutical purposes [26]. These processes are commonly less toxic and long-lasting.

\section{DRUG COMBINATION}

Drug combinations have been a paradigm for the management of many refractory diseases, such as cancer metastasis [37 - 40], HIV/AIDS treatments [41 - 43] etc. Since diabetes, especially T2DM exhibits wider spectra of symptoms, complications and genetic alterations in individual patients that need drug combination to overcome. A lot of questions should be answered - including how to choose drug combination before clinical applications. In our past arguments, optimal drug combination could be greatly improved from the therapeutic study of each possibility [37, 38]. It is however still at infancy stage currently.

Currently, even though a number of drug combinations have been utilized in clinical anti-diabetic treatments, theoretical medical studies are lag behind. Now clinical drug combinations are generally learned from doctors' empirical and instinct rather than modern diagnostic supporting. In the future, clinical drug combination should be verified in each possibility $[39,40]$. This type of medical work must be introduced from other medical disciplines, like cancer treatments [41, 42] and HIV/AIDS [41 - 43]. Let's pay more attention to this matter in the future.

\section{LIFESTYLE ADJUSTMENTS}

Lifestyle adjustments mainly represent physical exercises as well as food intake precaution. In this practice, exercise duration, intensity and regularity must be noticed. Lifestyle adjustments and drug therapy is a famous clinical paradigm worldwide.

\section{DISEASE CO-MORBIDITY AND COMPLICATIONS}

\subsection{Clinical Conditions}

Diabetes co-morbidity and complications are a multitude. More seriously, most of them are even life-threatening if 
we do not prepare for them. Large parts of disease complications are difficult to be a reversal after their advents. As a result, diabetic-induced complication treatment study must be strengthened in the futures. This strategy is indispensable yet only a few of them, such as Propolis or $\alpha$-thioctic acids are entered into markets. In co-morbidity disease, metabolic changes and chronic infections are widely presented [44 - 52] (Table 3).

Table 3. Major co-morbidity and complications in patients with T2DM [44 - 52].

\begin{tabular}{|c|c|}
\hline Complication Categories & Co-morbidity \\
\hline Metabolic & Cardiovascular (atherosclerosis, hypertension, stroke) \\
Obesity \\
& $\begin{array}{c}\text { Muscle malformations } \\
\text { Osteoporosis } \\
\text { Keton-urea }\end{array}$ \\
\hline Eye complications & $\begin{array}{c}\text { Visual damage and blur } \\
\text { Cataract }\end{array}$ \\
\hline Infections & Fundus hemorrhages and vessel leakage \\
\hline Kidney failure & Skin \\
Legs
\end{tabular}

\subsection{Co-Morbidity and Therapy}

Many diabetic-induced complications are associated with blood AGE (advanced glycation end products) escalated by glucose metabolisms in the patient body. To those T2DM patients with higher blood AGE, propolis, $\alpha$-thioctic acids and so on can reduce AGE and disease complications for a long-term. Correspondingly, drug combinations are unavoidable.

\section{FUTURE PERSPECTIVES}

\subsection{Key Medical Challenge}

Presently, anti-diabetic therapeutics has been standardized (Table 4). Expensive or cheap drugs are not parallel between their efficacy and costs. Since a growing number of patients are suffering from T2DM and co-morbidity worldwide. Anti-diabetic therapy studies need to boost. Persistent efforts and novel ideas are driving force for relevant drug developments (Fig. 3). Table 5 categorizes major avenues for achieving effective therapeutics in the future.

Table 4. The common therapeutic drugs in clinical diabetes treatments.

\begin{tabular}{|c|c|c|}
\hline Drug and Therapy & Mechanisms of Action & Adverse Events \\
\hline Insulin and its derivatives & Glucose metabolisms & Not significance \\
\hline Sulphonylurea & Stimulate insulin secretions & $\begin{array}{c}\text { Gastrointestinal }(20-30 \%) \\
\text { Infections }(20 \%)\end{array}$ \\
\hline Biguanide (Metforrnin) & Decrease amount of sugar productions by liver & Metabolisms \\
\hline $\begin{array}{l}\text { Acarbose } \\
\text { Voglibose }\end{array}$ & $\alpha$-glucosidase inhibitors & Gastrointestinal (20-30\%) \\
\hline Pioglitazone & Receptor agonists & $\begin{array}{c}\text { Heart failure }(1-5 \%) \\
\text { Bladder carcinoma }(1-2 \%)\end{array}$ \\
\hline Exercise & Mimics insulin actions & Not significance \\
\hline $\begin{array}{l}\text { Curcumin } \\
\text { Resveratol }\end{array}$ & $\begin{array}{c}\text { Plant chemicals } \\
\text { Wider biochemical pathways }\end{array}$ & Low \\
\hline Other melbine & Variable & Variability \\
\hline$\alpha$-thioctic acids (Lipoic acid) & Disease complications & Not obvious \\
\hline New anti-diabetic drugs & $\begin{array}{l}\text { SGLT-2 inhibition } \\
\text { DPP4 antagonists }\end{array}$ & Under investigations \\
\hline
\end{tabular}


Table 5. Main avenues for anti-diabetic treatment and clinical developments.

High therapeutic-indexed drug developments
Educate wider ranges of audience to know the basic diabetic information
Deeper understanding the relationship between causality, pathogenesis and therapeutics
Genetic, epigenetic or molecular study of all relevant disciplines.
Pearn from minority medicines - such as Traditional Chinese Medicine, Indian/Pakistan medicine, middle-east medicine and so on
Personalized diabetes therapy
Establish therapeutics against disease complications
Drug combination study, both experimentally and clinically
Strengthen the scientific investigations of biotherapeutic activity and pharmaceutical delivery systems
Budget control in drug developments and cost-effective in clinical trials
Find out some genetic targets from human genomes
Find out some small-molecular synthetic or natural cheming and receptors-binding activities
Genome Wide Association Study (GWAS) between patients and normal people
Invite mathematic-/physics-majored scholars in anti-diabetic study
Pharmaceutical innovation of insulin treatments from needle to oral
Global cooperation in foundation areas

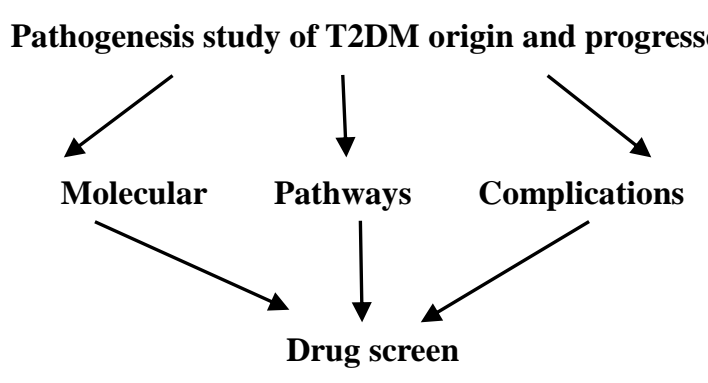

(Synthetic, natural and biological)<smiles>C[12CH2]</smiles>

\section{Preclinical and clinical}

(ADME, tolerance and toxicity)

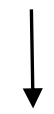

\section{Therapeutic evaluations}

(Symptom control and statistics)

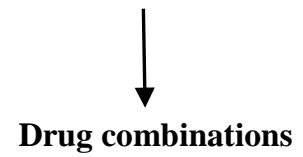

(Evidence collections and theoretic)

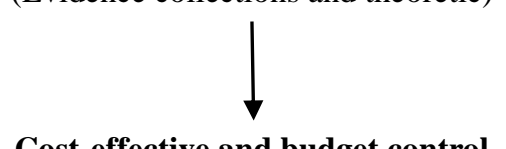

\section{Cost-effective and budget control}

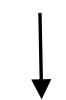

\section{Personalized medicines}

(Pharmacogenomics, bioinformatics, metabolomics and so on)

Fig. (3). Overall drug development and clinical utilities. 


\subsection{Therapeutic Limitations}

Co-morbidity and complications is a top priority and of great medical/pharmacology significance [52 - 55]. Since the relationship between hyperglycemia and co-morbidity symptoms has not been fully established, it is difficult to battle both sides of etio-pathologic processes.

Since too many pathologic molecules, components, steps and pathways can be changed in patients with T2DM, more patents for diabetic treatments are welcome across the world [53 - 55]. Continuing financial supports for antidiabetic study are indispensable, especially genomic study and mathematical or computational study [56 - 58].

\section{CONCLUSION}

Treatment of patients with T2DM is still a medical challenge for a diversity of disease originality, pathogenesis and therapeutics of cutting-edge (new generations of biotherapies) and traditional (herbal or insulin-related). Certainly, optimal therapeutic strategies by traditional and new drugs in the clinic are a trendy movement. The healthy dissemination of diabetic knowledge to a wider audience is an excellent avenue in diabetic epidemic control. In the future, medical perspectives and novel drug developments will be implemented for changing the landscape of antidiabetic therapeutic study.

\section{CONSENT FOR PUBLICATION}

Not applicable.

\section{CONFLICT OF INTERESTS}

The authors declare no conflict of interest, financial or otherwise.

\section{ACKNOWLEDGEMENTS}

This work was funded by Shanghai Science and Technology Foundation of High Educations 97A49.

\section{REFERENCES}

[1] Yang W, Lu J, Weng J, et al. Prevalence of diabetes among men and women in China. N Engl J Med 2010; 362(12): 1090-101. [http://dx.doi.org/10.1056/NEJMoa0908292] [PMID: 20335585]

[2] Lu DY, Che JY, Yarla NS, et al. Diabetes prevention and treatments, a specific topic for modern medicines. J Metab Syndr 2017 ; 8(3): 231.

[3] Zimmet PZ, Magliano DJ, Herman WH, Shaw JE. Diabetes: A 21 ${ }^{\text {st }}$ century challenge. Lancet Diabetes Endocrinol 2014; $2(1)$ : 56-64. [http://dx.doi.org/10.1016/S2213-8587(13)70112-8] [PMID: 24622669]

[4] Fuchs S, Henschke C, Blümel M, Busse R. Disease management programs for type 2 diabetes in Germany: A systematic literature review evaluating effectiveness. Dtsch Arztebl Int 2014; 111(26): 453-63. [PMID: 25019922]

[5] Thepwongsa I, Kirby C, Schattner P, Shaw J, Piterman L. Type 2 diabetes continuing medical education for general practitioners: What works? A systematic review. Diabet Med 2014; 31(12): 1488-97. [http://dx.doi.org/10.1111/dme.12552] [PMID: 25047877]

[6] Nannapaneni S, Ramar K, Surani S. Effect of obstructive sleep apnea on type 2 diabetes mellitus: A comprehensive literature review. World J Diabetes 2013; 4(6): 238-44. [http://dx.doi.org/10.4239/wjd.v4.i6.238] [PMID: 24379913]

[7] Grimaccia F, Kanavos P. Cost, outcomes, treatment pathways and challenges for diabetes care in Italy. Global Health 2014; $10(1)$ : 58. [http://dx.doi.org/10.1186/1744-8603-10-58] [PMID: 25024101]

[8] Lu DY, Che JY, Wu HY, et al. Obesity, risks and managements. Metabolomics 2018; 8(1): e156.

[9] Lu DY, Che JY, Lu Y, et al. An overview of obesity. Metabolomics 2018; 8(2): 200.

[10] Wens J, Vermeire E, Hearnshaw H, Lindenmeyer A, Biot Y, Van Royen P. Educational interventions aiming at improving adherence to treatment recommendations in type 2 diabetes: A sub-analysis of a systematic review of randomised controlled trials. Diabetes Res Clin Pract 2008; 79(3): 377-88.

[http://dx.doi.org/10.1016/j.diabres.2007.06.006] [PMID: 17643546] 
[11] Lu DY, Che JY, Wu HY, Lu TR. The pathogenesis and treatments of diabetes, questions and answers. Cell Dev Biol 2014; 3(3): e126.

[12] Lu DY, Che JY, Wu HY, Lu TR. The pathogenesis and treatments of diabetes, a new insight. Adv Tech Biol Med 2014; 2 : e102.

[13] Steculorum SM, Paeger L, Bremser S, et al. Hypothalamic UDP increases in obesity and promotes feeding via P2Y6-dependent activation of AgRP neurons. Cell 2015; 162(6): 1404-17.

[http://dx.doi.org/10.1016/j.cell.2015.08.032] [PMID: 26359991]

[14] Abdulazeez J, Tanko J, Salihu KI, et al. Prevention of oxidative stress by taurine in alloxan-induced Diabetic Mellitus in Wistar rats. EC Pharmacol Toxicol 2018; 6(80): 707-18.

[15] Lee YS, Kim JW, Osborne O, et al. Increased adipocyte $\mathrm{O}_{2}$ consumption triggers HIF-1 $\alpha$, causing inflammation and insulin resistance in obesity. Cell 2014; 157(6): 1339-52. [http://dx.doi.org/10.1016/j.cell.2014.05.012] [PMID: 24906151]

[16] Rosato V, Tavani A, Gracia-Lavedan E, et al. Type 2 diabetes, antidiabetic medications, and colorectal cancer risks: two case-control studies from Italy and Spain Front Oncol 2016. [http://dx.doi.org/10.3389/fonc.2016.00210]

[17] Asche C, LaFleur J, Conner C. A review of diabetes treatment adherence and the association with clinical and economic outcomes. Clin Ther 2011; 33(1): 74-109.

[http://dx.doi.org/10.1016/j.clinthera.2011.01.019] [PMID: 21397776]

[18] Matthews DR, Hosker JP, Rudenski AS, Naylor BA, Treacher DF, Turner RC. Homeostasis model assessment: Insulin resistance and betacell function from fasting plasma glucose and insulin concentrations in man. Diabetologia 1985; 28(7): 412-9. [http://dx.doi.org/10.1007/BF00280883] [PMID: 3899825]

[19] Maida A, Lamont BJ, Cao X, Drucker DJ. Metformin regulates the incretin receptor axis via a pathway dependent on peroxisome proliferatoractivated receptor- $\alpha$ in mice. Diabetologia 2011; 54(2): 339-49. [http://dx.doi.org/10.1007/s00125-010-1937-z] [PMID: 20972533]

[20] Evans WE, Johnson JA. Pharmacogenomics: the inherited basis for interindividual differences in drug response. Annu Rev Genomics Hum Genet 2001; 2: 9-39.

[http://dx.doi.org/10.1146/annurev.genom.2.1.9] [PMID: 11701642]

[21] Evans WE, Relling MV. Moving towards individualized medicine with pharmacogenomics. Nature 2004; 429(6990): 464-8. [http://dx.doi.org/10.1038/nature02626] [PMID: 15164072]

[22] Goldstein DB, Tate SK, Sisodiya SM. Pharmacogenetics goes genomic. Nat Rev Genet 2003; 4(12): $937-47$. [http://dx.doi.org/10.1038/nrg1229] [PMID: 14631354]

[23] Lu DY, Lu TR, Xu B, Ding J. Pharmacogenetics of cancer therapy: Breakthroughs from beyond? Future Sci OA. 2015, 1 (4), FSO.15, 80 [http://dx.doi.org/10.4155/fso.15.80]

[24] Corrêa-Giannella ML, Machado UF. SLC2A4gene: A promising target for pharmacogenomics of insulin resistance. Pharmacogenomics 2013; 14(8): 847-50.

[http://dx.doi.org/10.2217/pgs.13.45] [PMID: 23746177]

[25] Lu DY, Che JY. Rethink of diabetes treatment and drug development. Cell Dev Biol 2014; $3(2)$ : e125.

[26] Sattar N. Advances in managing type 2 diabetes: Challenging old paradigms and developing new ones. F1000Prime Rep 2014; 6: 42. [http://dx.doi.org/10.12703/P6-42] [PMID: 24991419]

[27] Lu DY, Lu TR, Xu B, Ding J. Pharmacogenetics of cancer therapy: Breakthroughs from beyond? Future Sci OA. 2015, 1 (4), FSO.15, 80 [http://dx.doi.org/10.4155/fso.15.80]

[28] Rys P, Pankiewicz O, Łach K, Kwaskowski A, Skrzekowska-Baran I, Malecki MT. Efficacy and safety comparison of rapid-acting insulin aspart and regular human insulin in the treatment of type 1 and type 2 diabetes mellitus: A systematic review. Diabetes Metab 2011; 37(3): $190-200$.

[http://dx.doi.org/10.1016/j.diabet.2010.12.003] [PMID: 21333580]

[29] Henry RR, Chilton R, Garvey WT. New options for the treatment of obesity and type 2 diabetes mellitus (narrative review). J Diabetes Complications 2013; 27(5): 508-18.

[http://dx.doi.org/10.1016/j.jdiacomp.2013.04.011] [PMID: 23726071]

[30] Turpin SM, Hoy AJ, Brown RD, et al. Adipose triacylglycerol lipase is a major regulator of hepatic lipid metabolism but not insulin sensitivity in mice. Diabetologia 2011; 54(1): 146-56. [http://dx.doi.org/10.1007/s00125-010-1895-5] [PMID: 20842343]

[31] Davis TME, Ting R, Best JD, et al. Effects of fenofibrate on renal function in patients with type 2 diabetes mellitus: The Fenofibrate Intervention and Event Lowering in Diabetes (FIELD) Study. Diabetologia 2011; 54(2): 280-90. [http://dx.doi.org/10.1007/s00125-010-1951-1] [PMID: 21052978]

[32] Ali I, Saleem K, Uddin R, Haque A, El-Azzouny A. Natural products: Human friendly anti-cancer medications. Egypt Pharm J 2010; 9(2): 133-79.

[33] Lu DY, Lu TR, Lu Y, Sastry N, Wu HY. Discover natural chemical drugs in modern medicines. Metabolomics 2016; 6(3): 181. 
[34] Wagh VD. Propolis: A wonder bees product and its pharmacological potentials. Adv Pharmacol Sci 2013 ; $2013: 308249$. [http://dx.doi.org/10.1155/2013/308249] [PMID: 24382957]

[35] Ahmed ZAE, Eltayeb TM, Mohamed HA, Mohmed NEB. Anti-bacterial activity of honey and Aacia nilotica extract against Aerobic bacteria isolated from diabetic wound. EC Microbiology 2018; 14(7): 408-13.

[36] Lu DY, Che JY, Yarla NS, et al. Type 2 diabetes, medical knowledge and pharmaceutical innovation. J Diabetology 2017; 1(1): 1-3.

[37] Lu DY, Chen EH, Lu TR, Ding J. Anticancer drug combinations, studies from different pathways. Cell Dev Biol 2015; 4(5): 166.

[38] Lu DY, Chen EH, Lu TR, Ding J. Anticancer drug combinations, studies for all possibilities. Adv Pharmacoepidemiol Drug Saf 2016; 5(1): e138.

[39] Lu DY, Chen EH, Wu HY, Lu TR, Xu B, Ding J. Anticancer drug combination, how far we can go through? Anticancer Agents Med Chem 2017; 17(1): 21-8. [PMID: 27039923]

[40] Lu DY, Lu TR, Yarla NS, et al. Drug combination in clinical cancer treatment. Rev Recent Clin Trials 2017; 12(3): 202-11. [http://dx.doi.org/10.2174/1574887112666170803145955] [PMID: 28782482]

[41] Pomerantz RJ, Horn DL. Twenty years of therapy for HIV-1 infection. Nat Med 2003; 9(7): 867-73. [http://dx.doi.org/10.1038/nm0703-867] [PMID: 12835707]

[42] Lu DY, Lu TR, Che JY, Wu HY, Xu B. New perspectives of HIV/AIDS therapy study. Recent Pat Antiinfect Drug Discov 2014; 9(2): 112-20. [http://dx.doi.org/10.2174/1574891X10666150109115402] [PMID: 25578060]

[43] Lu DY, Wu HY, Yarla NS, Xu B, Ding J, Lu TR. HAART in HIV/AIDS treatments, future trends. Infect Disord Drug Targets 2018; 18(1): $15-22$. [http://dx.doi.org/10.2174/1871526517666170505122800] [PMID: 28474549]

[44] Freire MDM, Alves C. Therapeutic Chinese exercises (Qigong) in the treatment of type 2 diabetes mellitus: A systematic review. Diabetes Metab Syndr 2013; 7(1): 56-9. [http://dx.doi.org/10.1016/j.dsx.2013.02.009] [PMID: 23517799]

[45] Li G, Zhang P, Wang J, et al. Cardiovascular mortality, all-cause mortality, and diabetes incidence after lifestyle intervention for people with impaired glucose tolerance in the Da Qing Diabetes Prevention Study: A 23-year follow-up study. Lancet Diabetes Endocrinol 2014; 2(6): 474-80.

[http://dx.doi.org/10.1016/S2213-8587(14)70057-9] [PMID: 24731674]

[46] Verma S, Farkouh ME, Yanagawa B, et al. Comparison of coronary artery bypass surgery and percutaneous coronary intervention in patients with diabetes: A meta-analysis of randomised controlled trials. Lancet Diabetes Endocrinol 2013; 1(4): $317-28$. [http://dx.doi.org/10.1016/S2213-8587(13)70089-5] [PMID: 24622417]

[47] (a) Lu DY, Che JY, Shen Y. Osteoporosis in old women, therapeutic selection. EC Orthopaedics 2018: 9(7); 386. (b) Lu DY, Che JY, Shen Y. Osteoporosis, importance for early diagnosis and treatment. EC Orthopaedics 2018: 9(9); 624-5.

[48] Biessels GJ, Strachan MWJ, Visseren FLJ, Kappelle LJ, Whitmer RA. Dementia and cognitive decline in type 2 diabetes and prediabetic stages: Towards targeted interventions. Lancet Diabetes Endocrinol 2014; 2(3): 246-55. [http://dx.doi.org/10.1016/S2213-8587(13)70088-3] [PMID: 24622755]

[49] Leroux C, Brazeau AS, Gingras V, Desjardins K, Strychar I, Rabasa-Lhoret R. Lifestyle and cardiometabolic risk in adults with type 1 diabetes: A review. Can J Diabetes 2014; 38(1): 62-9. [http://dx.doi.org/10.1016/j.jcjd.2013.08.268] [PMID: 24485215]

[50] Inan B, Aydin U, Ugurlucan M, Aydin C, Teker ME. Surgical treatment of lower limb ischemia in diabetic patients - long-term results. Arch Med Sci 2013; 9(6): 1078-82. [http://dx.doi.org/10.5114/aoms.2013.39630] [PMID: 24482653]

[51] Knowler WC, Bahnson JL, Bantle JP, et al. Effect of a long-term behavioural weight loss intervention on nephropathy in overweight or obese adults with type 2 diabetes: A secondary analysis of the Look AHEAD randomised clinical trial. Lancet Diabetes Endocrinol 2014; 2(10): 801-9. [http://dx.doi.org/10.1016/S2213-8587(14)70156-1] [PMID: 25127483]

[52] Soleimanpour SA, Gupta A, Bakay M, et al. The diabetes susceptibility gene Clec16a regulates mitophagy. Cell 2014; 157(7): 1577-90. [http://dx.doi.org/10.1016/j.cell.2014.05.016] [PMID: 24949970]

[53] Metabolex Inc. Use of (-)(3-trihalomethylphenoxy)(4-halophenyl) acetic acid derivatives for treatment of type 2 diabetes. US8329749 (2012).

[54] Metabolex Inc. N-linked heterocyclic receptor agonists for the treatment of diabetes and metabolic disorders. US20120322804A1 (2012).

[55] Yang W, Liu J, Shan Z, et al. Acarbose compared with metformin as initial therapy in patients with newly diagnosed type 2 diabetes: An open-label, non-inferiority randomised trial. Lancet Diabetes Endocrinol 2014; 2(1): 46-55. [http://dx.doi.org/10.1016/S2213-8587(13)70021-4] [PMID: 24622668]

[56] Lu DY, Lu TR. Mathematics or physics-majored students on the biomedical fields, insiders or outsiders? Metabolomics 2015; 5(4): e142.

[57] Lu DY, Wu HY, Lu TR, Che JY, Lu Y. Updating biomedical studies by recruiting more mathematics or physics-majored talents. 
Metabolomics 2016; 6(2): e148

[58] Lu DY, Lu TR, Lu Y, Wu HY, Yarla NS. The acquisition of mathematical language in biomedical articles. J Cell Developmental Biol 2017; 1(1): 8 .

\section{(C) $2018 \mathrm{El} \mathrm{Lu}$ et al.}

This is an open access article distributed under the terms of the Creative Commons Attribution 4.0 International Public License (CC-BY 4.0), a copy of which is available at: https://creativecommons.org/licenses/by/4.0/legalcode. This license permits unrestricted use, distribution, and reproduction in any medium, provided the original author and source are credited. 